\title{
Grassflies (Diptera: Chloropidae) of Chukotka, Russia
}

\section{ЗАаковые мухи (Diptera: Chloropidae) Чукотки, Россия}

\author{
E. P. Nartshuk ${ }^{1} \&$ O.A. Khruleva ${ }^{2}$ \\ Э.П. Нарчук, О.А. Хрулёва
}

\begin{abstract}
${ }^{1}$ Zoological Institute of Russian Academy of Sciences, Universitetskaya nab. 1, St. Petersburg 199034, Russia. E-mail: chlorops@zin.ru
1 Зоологический институт РАН,Университетская наб. 1, С.-Петербург 199034, Россия.

${ }^{2}$ Severtsov institute of ecology and evolution RAS, Leninsky pr. 33, Moscow 119071, Russia. E-mail: 1sdc@mail.ru

${ }^{2}$ Институт проблем экологии и эволюции им. А.Н. Северцова РАН, Ленинский пр. 33, Москва 119071 , Россия.
\end{abstract}

KEY WORDS: Diptera, Chloropidae, Chukotka, new faunistic data.

КЛЮЧЕВЫЕ СЛОВА: двукрылые насекомые, злаковые мухи, Чукотка, новые фаунистические данные.

ABSTRACT. Thirteen species of Chloropidae (Diptera) are recorded in Chukotka Autonomous District, 5 species are found for the first time, from them Epichlorops aquilonius Wheeler, 1994 is firstly recorded in the Palaearctic Region. Localities, distribution and biology of every species are listed.

РЕЗЮМЕ. На территории Чукотского Автономного округа отмечено 13 видов злаковых мух, 5 видов указываются впервые, из них Epichlorops aquilonius Wheeler, 1994 впервые найден в Палеарктике. Приводятся места находок, общее распространение и биология перечисленных видов.

\section{Introduction}

Diptera are one of the most diverse and abundant groups of insects in the Arctic, that play an important part in the tundra cenoses [Chernov, 1995; Gorodkov, 1997]. A number of carnivorous and saprophagous species in the Arctic fauna is usually higher than that of phytophagous ones as compared with other bioms [Danks, 1990; Chernov, 2002]. Chloropidae, a big family of Acalyptratea flies, include species with various trophic specialization of larvae, but in the Palaearctic fauna most species have phytophagous larvae associated with monocotyledons: grasses (Poaceae) and sedges (Cyperaceae), plants, that are important in zonal tundra communities. In this connection, is of interest to study the distribution of Chloropidae on the territory of Chukotka, one of the most northern territory of the Palaearctic. Apart from the review of the northern distribution of grassiflies [Nartshuk, 2005], where some species were mapped on Chukotka, there are two publications on Chloropidae of this region. In the paper on Chloropidae of Kamchatka Nartshuk [1963] recorded there 6 species from two localities of southern Chukotka. Nartshuk and Khruleva [2011] mentioned of a species at Wrangel Island. In this paper we record all the known species pointing to exact localities and biotopes. This information expands our knowledge about specific features of the grassfly species diversity and their distribution on the North.

\section{Material}

Flies were collected by K.B. Gorodkov in 1959 , 1963, 1966, 1971, 1972 in different localities of Chukotka. O.A. Khruleva collected grassflies in June and July 2011 in the vicinity of the town of Pevek. The territory of Chukotka AD is characterized by the high diversity of climatic and landscape conditions, from the northern taiga (at the south-west part) to the arctic tundra subzones, located by a narrow belt along the northern sea coast [Yurtsev et al., 2010]. The majority of the investigated localities is situated in the tundra zone of Chukotka. The localities studied are mapped (Fig.). The whole material is deposited in the collection of the Zoological

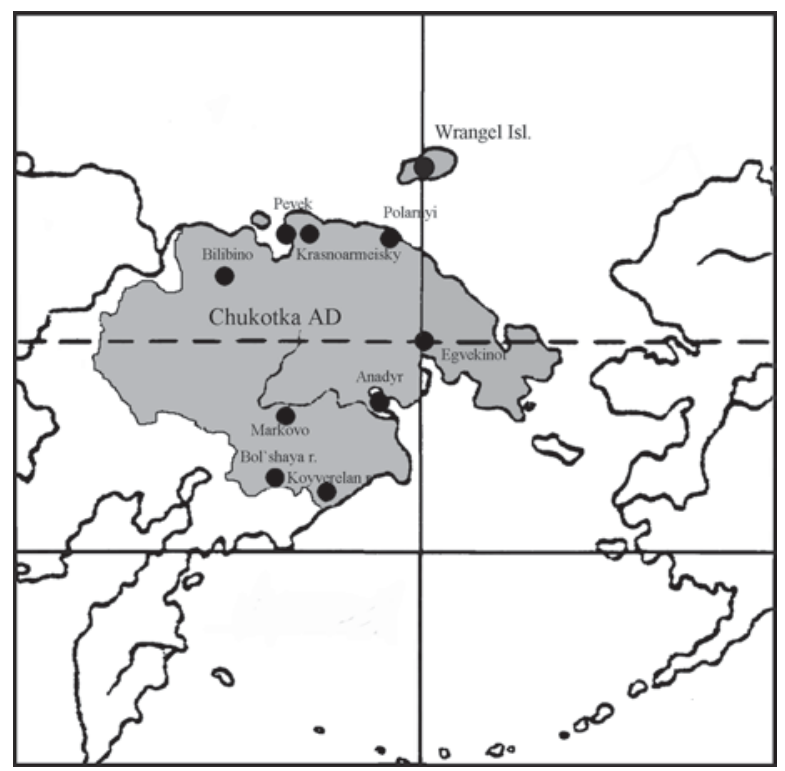

Figure. Sites of the grassfly collections in Chukotka AD. Рис. Места сбора злаковых мух в Чукотском АO 
institute of Russian Academy of Sciences (St. Petersburg). Abbreviations of collectors in the list are as follows: $\mathrm{G}$ - K.B. Gorodkov, $\mathrm{Kh}-$ O.A. Khruleva.

\section{Annotated list of species}

\section{Subfamily Oscinellinae \\ 1. Conioscinella frontella (Fallén, 1820)}

MATERIAL. Markovo, meadow among bushes, 18.08.1966 (G), 1 sp.

Transpalaearctic species with phytophagous larvae on Poaceae. Species is recorded on Chukotka for the first time.

\section{Elachiptera cornuta (Fallén, 1820)}

MATERIAL. Bilibino, swamp, 5.07.1971 (G); Apappelgin, 15 km NE Pevek, 1.071972 (G); Markovo, 18.08.1966 (G). Total 9 sps.

Transpalaearctic species with saprophagous larvae.

\section{Gaurax paradoxocerus Nartshuk, 1963}

MATERIAL. Koyverelan river, $63^{\circ} 05^{\prime} \mathrm{N}, 175^{\circ} 00^{\prime} \mathrm{E}$, bushes in the valley, $200 \mathrm{~m}$ a. s. 1., 8.07.1959 (G), $1 \mathrm{sp}$.

The species was described from this locality and did not find later, larvae of species of the genus usually live in rotting wood.

\section{Lasiambia palposa (Fallén, 1820)}

MATERIAL. Vicinity of Pevek, $69^{\circ} 40^{\prime} \mathrm{N}, 170^{\circ} 16^{\prime} \mathrm{E}$, dampish slope facing NW with semishrub (dwarf willows, dryad)-moss vegetation, $201 \mathrm{~m}$ a.s.1., 29.06 .2011 (Kh), $1 \mathrm{sp}$.

Euro-Siberian species with carnivorous larvae. Species is recorded on Chukotka for the first time.

\section{Oscinella frit (Linnaeus, 1858)}

MATERIAL. Vicinity of Pevek, $69^{\circ} 40^{\prime} \mathrm{N}, 170^{\circ} 16^{\prime} \mathrm{E}$, burrow of ground squirrel with lighted moss-grass-gramineous vegetation on the southern slope of hill, 27.06.2011 (Kh), Pevek, on flowers on the burrow of ground squirrel, 11.07.1963 (G); placer mine Krasnoarmeysky, valley of the Ichuviem river, dead channel with sedge, 8.07.1963 (G); the same locality, shrub tundra and willow thickets in the bottomland, 5-7.07.1963 (G); Markovo, coast of river with Salix, 18.08.1966 (G); upper reache of the Bol'shaya river, shrub tundra, 23.07.1959 (G). Total 23 sps.

Widely distributed subcosmopolitan species, larvae phytophagous on Poaceae. 25 flies of this species were collected on Wrangel Island in 2006 [Nartshuk \& Khruleva, 2011].

\section{Siphonella oscinina (Fallén, 1820)}

MATERIAL. Koyverelan river, $63^{\circ} 05^{\prime} \mathrm{N}, 175^{\circ} 00^{\prime} \mathrm{E}$, bushes in the valley, $200 \mathrm{~m}$ a. s. 1., 26.07.1959 (G), 1 sp.

Holarctic species, larvae, probably, carnivorous.

\section{Subfamily Chloropinae}

\section{Chlorops gorodkovi Smirnov et Fedoseva, 1976}

MATERIAL. Lower reach of the Apappelgin river, $20 \mathrm{~km} \mathrm{NE}$ Pevek, $69^{\circ} 48^{\prime} \mathrm{N}, 170^{\circ} 39^{\prime} \mathrm{E}$, horsetail-grass meadow with single bush of willows on the western slope of the river valley terrace, 22.07.2011 (Kh); Koyverelan river, $63^{\circ} 05^{\prime} \mathrm{N}, 175^{\circ} 00^{\prime} \mathrm{E}$, bushes in the valley, $200 \mathrm{~m}$ a. s. 1., 28.07.1959 (G). Total 12 sps.

The species was described from the Koyverelan river, was found in Yakutia as well. Larvae are phytophagous, as all larvae of the genus species.

\section{Chlorops scutellaris (Zetterstedt, 1838)}

MATERIAL. Vicinity of Pevek, $69^{\circ} 42^{\prime} \mathrm{N}, 170^{\circ} 21^{\prime} \mathrm{E}$, the foot of a hill of southern exposition, 5.07.2011 (Kh); patchy lichendryad-moss tundra near the sea coast, 7.07.2011 (Kh); Valkumey, $18 \mathrm{~km} \mathrm{~S}$ Pevek, $69^{\circ} 36^{\prime} \mathrm{N}, 170^{\circ} 13^{\prime} \mathrm{E}$, shrub tundra, the sea shore, southern slope, 13.07.1963 (G); 5 km N Egvekinot, 27.07.1963, a meadow near settlement $(\mathrm{G})$. Total 8 sps.

Euro-Siberian, arcto-montanous species. Larvae, probably, phytophagous, as all larvae of the genus species. Species is recorded on Chukotka for the first time.

\section{Epichlorops aquilonius Wheeler, 1994}

MATERIAL. Valkumey, 18 km S Pevek, 69 $36^{\circ}$ N, 170 $13^{\prime}$ E, dampish northern slope of hill with sedge-shrub-mosses vegetation, 29.07.2011 (Kh), $10^{7}$.

Species was described from Canada: Northwest Territories, $21 \mathrm{mi}$ E Tuktoyaktuk [Wheeler, 1994]. First record in the Palaearctic. The species is distinguished from E. puncticollis by colour of scutellum and structure of the male genitalia.

\section{Epichlorops puncticollis (Zetterstedt, 1848)}

MATERIAL. Vicinity of Pevek, $69^{\circ} 42^{\prime} \mathrm{N}, 170^{\circ} 21^{\prime}$ E, dampish mountainous terrace with grass-semishrub (ledum, dwarf birch and willow, cowberry)-moss vegetation and single climb willows, $251 \mathrm{~m}$ above sea level, pitfall traps, 7-18.07.2011(Kh); Valkumey, $18 \mathrm{~km}$ S Pevek, $69^{\circ} 36^{\prime} \mathrm{N}, 170^{\circ} 13^{\prime} \mathrm{E}$, shrub tundra, the sea shore, southern slope, 13.07.1963 $(\mathrm{G})$; upper reache of the Bol'shaya river, shrub tundra, 16.07.1959 (G). Total 5 sps.

Holarctic species, larvae live in rhizome of Eleoharis spp., probaply, saprophagous. Species is recorded on Chukotka for the first time.

\section{Pseudopachychaeta ruficeps (Zetterstedt, 1838)}

MATERIAL. Pevek, wet sedge-cotton grass tundra, 11.07.1963 (G); placer mine Krasnoarmeysky, valley of the Ichuviem river, dead channel with sedge, 8.07.1963 (G); placer mine Polarnyi, 84 km W Cape Shmidt, wet tundra, 2.08.1972, (G); Koyverelan river, $63^{\circ} 05^{\prime} \mathrm{N}, 175^{\circ} 00^{\prime} \mathrm{E}$, bushes in the valley, $200 \mathrm{~m}$ a. s. 1., 26.07.1959 (G); vicinity of Ugol'nye Kopi, N Anadyr, marsh with Eriophorum spp., 12.08.1966 (G). Total 18 sps.

Transpalaearctic species, larvae phytophagous, live in inflorescences of Eriophorum spp., feed unripe seeds.

\section{Thaumatomyia glabra (Meigen, 1830)}

MATERIAL. Bilibino, swamp, 5.071971 (G); vicinity of Pevek, $69^{\circ} 40^{\prime} \mathrm{N}, 170^{\circ} 16^{\prime} \mathrm{E}$, gravel slope facing $\mathrm{NW}$ with patchy grass-semichrub (dwarf willow, dryad, cowberry)-moss vegetation, $19.062011(\mathrm{Kh})$; lower reach of the Apappelgin river, $20 \mathrm{~km} \mathrm{NE}$ Pevek, $69^{\circ} 48^{\prime} \mathrm{N}, 170^{\circ} 39^{\prime} \mathrm{E}$, burrow of ground squirrel with grasswormseed-gramineous vegetation near a wet lake depression, 5.07 2011 (Kh); airport Anadyr, N coast, in settlement, 31.071963 (G). Total 5 sps.

Holarctic species, larvae carnivorous, live in ground and feed on root aphids.

\section{Thaumatomyia trifasciata (Zetterstedt, 1848)}

MATERIAL. Bilibino, swamp, 5.071971 (G); placer mine Krasnoarmeysky, Salix in valley of river, 8.071963 (G); airport Anadyr, N coast, in settlement, 31.071963 (G); 5 km N Egvekinot, a meadow near settlement, $27.071963(\mathrm{G})$. Total 8 sps.

Transpalaearctic species, larvae carnivorous, live in ground and feed on root aphids.

\section{Discussion}

A total of 93 specimens of Chloropidae were collected by two collectors during several field seasons. These data clearly demonstrate that Chloropidae species seldom occur in tundra biome. Only ten species from thirteen were found in the tundra zone of Chukotka, many of them occur also far to the south (Table). Only two species were found in the arctic tundra subzone of Chukotka 
Table. The distribution of the Chloropidae species in different phytogeographic subzones of Chukotka Таблица. Распространение видов Chloropidae в различных фитогеографических подзонах Чукотки

\begin{tabular}{|c|c|c|c|c|}
\hline \multirow{3}{*}{ Species } & \multicolumn{4}{|c|}{ Subzones } \\
\hline & \multirow{2}{*}{$\begin{array}{l}\text { Arctic } \\
\text { tundra }\end{array}$} & \multicolumn{2}{|c|}{ Hypoarctic: } & \multirow{2}{*}{$\begin{array}{l}\text { Elfin } \\
\text { wood- } \\
\text { land }\end{array}$} \\
\hline & & \begin{tabular}{|l|} 
middle \\
tundra
\end{tabular} & $\begin{array}{l}\text { southern } \\
\text { tundra }\end{array}$ & \\
\hline Conioscinella frontella & - & - & - & + \\
\hline Elachiptera cornuta & - & t & + & t \\
\hline Gaurax paradoxocerus & - & - & - & + \\
\hline Lasiambia palposa & - & t & - & - \\
\hline Oscinella frit & + & + & - & + \\
\hline Siphonella oscinina & - & - & - & + \\
\hline Chlorops gorodkovi & - & + & - & + \\
\hline Chlorops scutellaris & - & + & - & - \\
\hline Epichlorops aquilonius & - & + & - & - \\
\hline Epichlorops puncticollis & - & + & - & + \\
\hline Pseudopachychaeta muficeps & + & + & + & + \\
\hline Thaumatomyia glabra & - & + & + & - \\
\hline Thaumatomyia trifasciata & - & - & + & - \\
\hline
\end{tabular}

NOTE. Subzones adduced in accordance with Yurtsev et al [2010]. Localities of collections in different subzones: Arctic tundra: Wrangel Isl., Polarnyi; Hypoarctic middle tundra: Valkumey, Pevek, Apappelgin, Krasnoarmeisky, Evgekinot; Hypoarctic southern tundra: Bilibino, Anadyr, Ugol'nye Kopi; Elfin woodland: Markovo, Bol'shaya r., Koyverelan r.

ПРИМЕЧАНИЕ. Подзоны приведены по: Юрцев и др.[2010] Места сбора в различных подзонах. арктическая тундра: о-в Врангеля, Полярный; средняя тундра: Валькумей, Певек, Апаппельгин, Красноармейский, Эвгекинот; южная тундра: Билибино, Анадырь, Угольные копи; криволесье: Марково, р. Большая, р. Койверелан.

(Pseudopachychaeta ruficeps at placer mine Polarnyi, and Oscinella frit - on Wrangel Isl.). Both of them are among the most common grassflies in Chukotka as well as in the tundra zone. Four species were collected in the hypoarctic southern tundra subzone, and nine species in the hypoarctic middle (typical) tundra subzone. The greater number of the species found in the northern subzone is suggested to be associated with the fact that this area has received the most study. All of these nine species were found in the vicinity of Pevek (including Apappelgin and Valkymey). The species diversity of this locality was higher than it was found in the other ones of the tundra zone (including Chukotka), where not more than three or four grassfly species were collected. This fact may be also connected with the high diversity of landscape in this territory (plain and mountain areas) and the continental climate as well. These features determine contrasting thermal and moisture conditions under a wide range of relief elements and high diversity of plain communities. There are no species of Chloropidae with optimal distribution in plain landscapes situated to the north of the forest border [Nartshuk, 2005]. The number of species occurring in the northern boreal forest region significantly increases. This was demonstrated by the data on Chloropidae from Messaure (Swedish Lappland) situated in the northern boreal forest zone, where 19 species of Chloropidae were found [Nartshuk, 2003]. Species with different trophic specialization are presented in the fauna of Chukotka: 5 species with phytophagous larvae, 4 with carnivorous larvae, and 3 with saprophagous larvae. The share of species with carnivorous larvae is significantly greater than that in more southern local faunas of Chloropidae. Most species have vast ranges: multiregional - 1, Holarctic - 4, one of them Epichlorops aquilonius, described from North Canada, is firstly recorded in the Palaearctic, transpalaearctic and EuroSiberian - 6 species. Gaurax paradoxocerus is known from southern Chukotka only, and another East-Siberian species, Chlorops gorodkovis, is known from Chukotka and Yakutia.

ACNOWLEDGEMENTS. The work was supported by the Russian Foundation for Basic Research (projects \#\# 1004-00093a, 11-04-00185 and 11-04-00941) and the Programs "Biodiversity and dynamics of gene pools" and "Origin of biosphere and evolution of geobiological systems" of the Russian Academy of Sciences.

\section{References}

Chernov Yu.I. 1995. The order Diptera (Insecta) in the Arctic fauna // Zoologicheskyi zhurnal. Vol.74. No.5. P.68-83 [in Russian, english translation: Entomological Review. Vol.74. No.5. P. 117-134].

Chernov Yu.I. 2002. Biota of the Arctic: taxonomic diversity // Zoologicheskyi zhurnal. Vol.81. No.12. P.1411-1431 [in Russian, english translation: Entomological Review. 2003. Vol.82. Suppl.1. P.1-23].

Danks H.V. 1990. Arctic insects: Instructive diversity // C.R Harrington (ed.). Canada's missing dimension. Science and history in the Canadian arctic islands. Canadian Museum of Nature. Vol.2. P.444-470.

Gorodkov K.B. 1997. Changes in composition of Diptera fauna within the Arctic Region // O.A. Skarlato (ed.). The place and role of Diptera in ecosystems. Zoological institute of Academy of Sciences of the USSR. L. P.41-42 [in Russian].

Nartshuk E.P. 1963. To the knowledge of grassflies (Diptera, Chloropidae) of Kamchatka // Trudy Kamchatskoy kompleksnoi expeditsii. M.-L. P.106-112 [in Russian].

Nartshuk E.P. 2003. Chloropidae (Diptera, Muscomorpha) of the Swedish Lapland // Entomologisk Tidskrift. Vol.124. No.4. P.241-244.

Nartshuk E.P. 2005. Grassflies (Diptera, Chloropidae) in the Northern Palaearctic Region// Zoologicheskyi zhurnal. Vol.84. No.2. P.218-227 [in Russian, english translation: Entomological Review. 2005. Vol.85. No.3. P.244-254].

Nartshuk E.P. \& Khruleva O.A. 2011. Plant-feeder Diptera (Diptera, Chloropidae, Agromyzidae) from Wrangel Island (the Chukotsk Sea) // Zoologicheskyi zhurnal. Vol.90. No.9. P.1135-1140 [in Russian, english translation: Entomological Review. 2011. Vol.91. No.7. P.849-854].

Wheeler T. 1994. A revision of the genus Epichlorops Becker (Diptera, Chloropidae) // Entomologica Scandinavica. Vol.25. P.393-414.

Yurtsev B.A., Koroleva T.M., Petrovsky V.V., Polozova T.G., Zhukova P.G. \& Katenin A.E. 2010. Checklist of flora of the Chukotkan Tundra. St.-Petersburg: VVM Ltd Publishing. 628 p. 